\title{
PENGEMBANGAN MOBILE LEARNING BERBASIS ANDROID SEBAGAI MEDIA PEMBELAJARAN ORGANISASI ARSITEKTUR KOMPUTER
}

\author{
Aminda Dewi Sutiasih *, Renny Permata Saputri \\ Universitas Putra Indonesia YPTK Padang, Jl. Raya Lubuk Begalung, 25122 Indonesia \\ * Corresponding Author. Email: amindadewi@upiyptk.ac.id \\ Received: 24 October 2019; Revised: 28 October 2019; Accepted: 30 October 2019
}

\begin{abstract}
Abstrak
Optimalisasi penggunaan smartphone dalam proses pembelajaran masih rendah, maka sangat diperlukan merancang suatu proses pembelajaran dengan mengoptimalkan penggunaan smartphone. Penelitian ini bertujuan untuk merancang proses pembelajaran menggunakan smartphone dengan sistem mobile learning berbasis Android terhadap mata kuliah organisasi arsitektur komputer. Model yang digunakan adalah Instructional Development Institute (IDI) dalam metode Research and Development (R\&D). Hasil penelitian ini menunjukkan bahwa mobile learning yang dikembangkan valid untuk dimanfaatkan sebagai media pendukung pembelajaran, sesuai dengan hasil uji validitas yang dilakukan dengan pakar media serta pakar materi didapatkan hasil dari Perhitungan validasi materi yaitu validator 1 $(0,91)$, validator $2(0,95)$ dan validasi desain yaitu validator $1(0,9)$, validator $2(0,89)$, yang termasuk kategori valid. Hasil uji kepraktisan terhadap media pembelajaran mobile learning berbasis Android berdasar respon dosen adalah pada nilai rata-rata 92\%, dan berdasar respon mahasiswa adalah pada nilai rata-rata $87,61 \%$ yang termasuk kategori sangat praktis. Untuk uji efektifitas yang diujikan ke mahasiswa didapatkan hasil untuk kelas kontrol sebesar $74,56 \%$ dan eksperimen sebesar 82,25\%, sehingga penggunaan mobile learning berbasis Android ini valid, praktis dan efektif untuk dapat digunakan pada mata kuliah organisasi arsitektur komputer di Universitas Putera Indonesia YPTK Padang.

Kata Kunci: Mobile learning, organisasi arsitektur komputer, research and development
\end{abstract}

\section{ANDROID-BASED MOBILE LEARNING DEVELOPMENT AS A LEARNING MEDIA OF COMPUTER ARCHITECTURE ORGANIZATIONS}

\begin{abstract}
Optimizing the use of smartphones in the learning process is still low, so it is very necessary to design a learning process by optimizing the use of smartphones. This study aims to design the learning process using a smartphone with an Android-based mobile learning system for Computer Architecture Organization courses in universities. The model used is the Instructional Development Institute (IDI) in the Research and Development (RED) method. The results of this study indicate that mobile learning for computer architecture organization courses is valid to be used as a learning support media, in accordance with the results of the validity test conducted with media experts and material experts obtained from the Calculation of material validation namely validator 1 (0.91), validator 2 (0.95) and design validation, namely validator 1 (0.9), validator 2 (0.89), which is included in the valid category. The results of practicality tests on Android-based mobile learning media based on lecturer responses are at an average value of $92 \%$, and based on student responses is at an average value of $87.61 \%$ which is included in the very practical category. For the effectiveness test that is tested on students, the results for the control class were $74.56 \%$ and experiments were $82.25 \%$, so that the use of Android-based mobile learning is valid, practical and effective to be used in computer architecture organization courses at the University of Putera Indonesia YPTK Padang.
\end{abstract}

Keywords: Computer architecture organization, mobile learning, research and development

doi) http://dx.doi.org/10.21831/jitp.v6.1.15068 


\section{Pendahuluan}

Pada revolusi Industri 4.0, pendidikan di Indonesia harus menyesuaikan dengan perkembangan zaman. Kebanyakan perguruan tinggi belum dapat menyesuaikan perkembangan teknologi industri 4.0 kedalam proses pembelajarannya, meskipun telah banyak media pembelajaran yang sudah berhasil diterap-kan (Aditya, Nurhas \& Pawlowski, 2019, p. 30). Manfaat smartphone sangat luas terutama bagi mahasiswa dan tidak terbatas untuk bersosial media seperti facebook, instagram saja ataupun berselancar di dunia maya. Media merupakan perantara dalam proses pembelajaran, sehingga dapat me-nambah pengetahuan mahasiswa baik itu pengetahuan secara kognitif (berfikir), afektif (sikap), maupun keterampilan (psikomotorik) (Arsyad, 2016, p. 58). Semakin menariknya media pembelajaran yang digunakan dalam proses pembelajaran, maka semakin tinggi pula motivasi mahasiswa dalam mengingkatkan hasil belajarnya, yang dalam hal ini adalah Indeks Prestasi Kumulatif (IPK).

Metode pembelajaran di Indonesia kebanyakan masih terpaku pada pembelajaran secara tatap muka di kelas atau dengan metode ceramah (Faisal \& Martin, 2019, p. 3). Oleh karena itu, mobile learning berbasis Android sangat sesuai dengan perkembangan proses pembelajaran yang ada sekarang ini dan diharapkan dapat menghasilkan media pendukung pembelajaran yang mandiri bagi siswa. Teknologi yang berbasis online sangat efektif untuk digunakan dalam proses pembelajaran (Gregory \& Tyrrel, 2017, p. 5).

Salah satu perubahan atau perkembangan pada proses pembelajaran di perguruan tinggi yang perlu diperhatikan ialah perkembangan industri 4.0 yang salah satunya ialah penggunaan mobile learning. Mobile learning merupakan media pembelajaran yang menggunakan smartphone atau device sebagai media penyampaian informasi materi pembelajarannya untuk dapat menunjang proses pembelajaran. Sistem ini merubah pembelajaran tatap muka dikelas atau metode ceramah yang sangat konvensional, menjadi pembelajaran secara mandiri yang dapat dilakukan oleh siswa dengan menggunakan media pembelajaran berbasis Android yang dilengkapi dengan berbagai fitur seperti teks, gambar, video, audio, dan animasi dapat meningkatkan minat serta motivasi belajar mahasiswa dalam proses pembelajaran (Chatwattana \& Nilsook, 2017, p. 7).

Peranan mobile learning dalam proses pembelajaran yaitu dengan menggunakan aplikasi mobile learning sebagai media pendukung pembelajaran. Mobile learning dapat diakses kapanpun dan dimanapun tanpa mengenal ruang dan waktu karena sifatnya yang fleksibel. Dikatakan fleksibel karena mobile learning diinstal pada tiap-tiap smartphone atau gadget dari siswa atau user, yang mana kita ketahui bahwa sekarang ini smartphone telah menjadi kebutuhan pokok bagi beberapa kalangan. Kelas pembelajaran pada mobile learning tidak hanya dilakukan dalam perkuliahan saja, namun dapat dilakukan diluar jam perkuliahan. Mobile learning memberi kesempatan kepada mahasiswa untuk melakukan pembelajaran secara mandiri tanpa harus tergantung pada dosen pengampu. Dengan semakin berkembangnya pengguna smartphone, maka penggunaan smartphone tidak hanya digunakan untuk alat komunikasi saja, namun juga dapat dimanfaatkan untuk proses belajar mengajar (Darmawan, 2016, p.98).

Mobile learning dapat membuat smartphone yang biasanya digunakan untuk berkomunikasi, menjadi alat pembelajaran yang didalamya terdapat rancangan pembelajaran, materi pembelajaran, soalsoal latihan dan dilengkapi berbagai fitur seperti gambar, video dan animasi. Penggunaan smartphone sangat mempermudah pekerjaan semua orang termasuk penggunaan dalam media pembelajaran dan untuk berkomunikasi. Proses pembelajaran yang menggunakan mobile learning dapat meningkatkan efektifivitas dan aksebilitas kegiatan pembelajaran, sehingga 
dapat membuat mahasiswa antusias dalam pembelajaran (Bhati \& Song, 2019, p.183). Media pembelajaran mobile learning memberikan pelayanan kepada mahasiswa dengan lingkungan pendukungnya (Mogase \& Alexander, 2018, p.1002).

Penelitian mengenai Mobile Game Based Learning (Cahyana, Paristiowati, Nurhadi, Hasyrin, 2017, p. 145) bertujuan untuk dapat mengembangkan motivasi belajar siswa. Hasilnya adalah bahwa siswa merasa puas dan lebih tertarik dalam proses pembelajaran dengan menggunakan media pembelajaran mobile game based learning. Hal ini sejalan dengan penelitian mengenai pengembangan mobile learning (Kasatria, 2014, p. 243), yang mengatakan bahwa pengembangan mobile learning dalam proses pembelajaran dapat membantu dosen dan mahasiswa termasuk dalam pembagian tugas dan mengerjakan kuis. Mobile learning memiliki dampak yang sangat baik bagi pembelajaran karena melalui mobile learning mahasiswa juga dapat berhubungan dengan dosen pengampu serta peserta didik lainnya dengan mengandalkan koneksi dari internet. Teknologi yang ditawarkan oleh mobile learning tidak membatasi pembelajaran yang terpaku pada jadwal tatap muka. Oleh karena itu, penggunaan mobile learning dalam pembelajaran menawarkan kemajuan yang luar biasa di masa depan.

Penelitian ini dirancang dengan menggunakan software Macromedia Flash Animate CC sebagai media pendukung dan pengembangan pembelajaran mobile learning berbasis Android. Penelitian ini menghasilkan sebuah produk mobile learning yang kemudian diupload ke dalam Google Playstore agar mahasiswa atau pengguna dapat mengunduh dan menginstall di smartphone mereka masingmasing. Hasil penelitian ini diharapkan dapat meningkatkan efektifitas dan aksebilitas kegiatan pembelajaran dan mempermudah mahasiswa dalam penyelesaian tugas dan memahami materi pelajaran melalui smartphone mereka terutama pada mater organisasi arsitektur komputer.

\section{Metode Penelitian}

Perancangan mobile learning berbasis Android pada mata kuliah organisasi arsitektur komputer ditujukan untuk mahasiswa semester genap program studi Pendidikan Teknik Informatika Universitas Putera Indonesia YPTK Padang, Jl. Raya Lubuk Begalung, Padang, Sumatera Barat, Indonesia. Subjek penelitian sebanyak 32 orang. Metode penelitian yang digunakan dalam mengembangkan produk mobile learning berbasis Android pada penelitian ini menggunakan metode penelitian dan pengembangan (Research \& Development). Metode penelitian pengembangan ini merupakan metode penelitian yang digunakan untuk menghasilkan suatu produk mobile learning yang kemudian dianalisis untuk mendapatkan keefektifan dari produk tersebut (Sugiyono, 2015a, p.68).

Produk yang dihasilkan dari penelitian ini berupa perangkat lunak atau software. Untuk menghasilkan produk digunakan penelitian yang bersifat analisis kebutuhan dan untuk menguji keefektifan produk tersebut agar dapat berfungsi di masyarakat luas, maka diperlukan penelitian untuk menguji keefektifan produk tersebut. Ada sepuluh langkah dalam metode penelitian dan pengembangan (Sugiyono, 2015a, p.45) yang dapat dilihat pada Gambar 1.

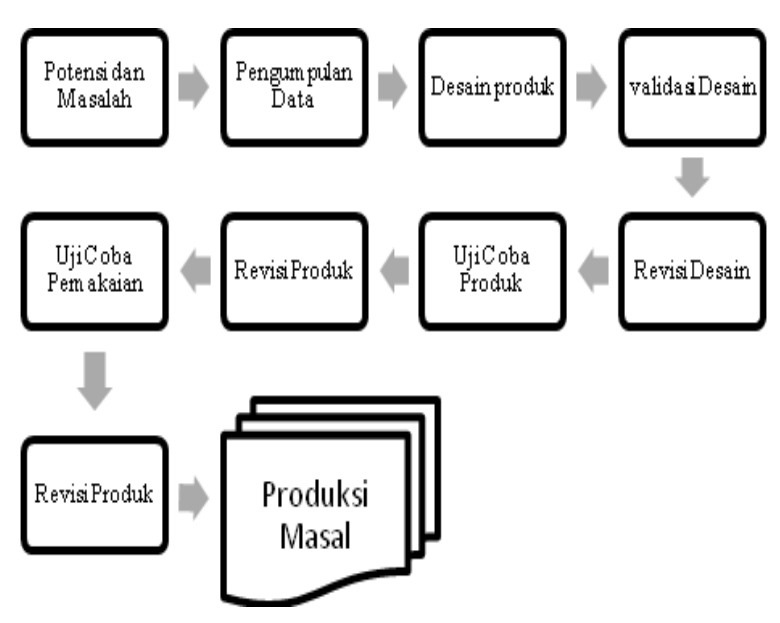

Gambar 1. Langkah dalam Metode Penelitian Dan Pengembangan 
Media pembelajaran mobile learning yang dikembangkan menggunakan model Instructional Development Institute (IDI). Model pengembangan ini mencakup tiga tahapan, yaitu: 1.) Tahap define yaitu tahap analisis kebutuhan; 2.) Tahap develop yaitu tahapan dalam pengembangan produk, dan 3.) Tahap evaluate yaitu tahap uji coba produk yang telah dikembangkan. Tahap pertama merupakan tahap penentuan yang bertujuan untuk menyusun dan mendefinisikan syarat-syarat pembelajaran. Tahap kedua merupakan tahap pengembangan produk yang bertujuan untuk merancang produk mobile learning dan kemudian dilakukan validasi terhadap produk yang telah dikembangkan. Tahap ketiga merupakan tahap penilaian yang bertujuan untuk mengevaluasi rancangan mobile learning dengan melakukan uji coba produk.

\section{Tahap Penentuan (Define)}

Tahap Penentuan (define) mencakup pelaksanaan penelitian diawali dengan menetapkan tujuan pengembangan dan mendefinisikan syarat-syarat pembelajaran yang terdiri dari analisis konsep dan analisis karakteristik mahasiswa. Tujuannya adalah untuk merangkum konsep-konsep utama dari materi organisasi arsitektur komputer yang akan dijadikan materi utama dari mobile learning yang akan dikembangkan. Konsep atau materi baik itu utama, maupun pendukung sangat diperhitungkan, sehingga mahasiswa menguasai apa yang akan dipelajarinya sesuai dengan pengetahuan dan keterampilan yang di milikinya.

\section{Tahap Pengembangan}

Tahap pengembangan mencakup perancangan prototype dan tahap validasi. Pada tahap ini dilakukan langkah-langkah yang dapat dilihat pada Gambar 2. Tahapan proses pembuatan aplikasi mobile learning berbasis Android dengan menggunakan software Macromedia Flash Animate CC dapat dijelaskan sebagai berikut: 1.) Tahap pengumpulan kebutuhan, yaitu dengan menyiapkan materi pelajaran yang didapat dari hasil diskusi antara dosen pengampu dan sumber lainnya; 2.) Tahap perancangan produk, yaitu pembuatan atau pengembangan aplikasi mobile learning berbasis Android dengan menggunakan software Macromedia Flash Animate CC; dan 3.) Tahap evaluasi produk, yaitu evaluasi terhadap aplikasi mobile learning yang telah dikembangkan oleh validator. Apabila masih terdapat kekurangan pada produk, maka dilakukan perulangan proses-proses sebelumnya, hingga produk aplikasi mobile learning sesuai dengan materi yang akan diajarkan dosen pengampu.

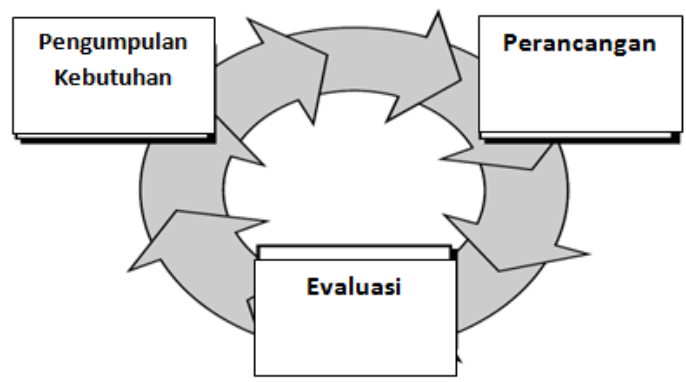

Gambar 2. Desain Model Prototype

Tahap Validasi

Pada tahap ini mobile learning yang telah dikembangkan divalidasikan oleh para ahli atau pakar. Validasi dilakukan terhadap aspek materi serta aspek media. Data yang diperoleh dalam penelitian akan dianalisis secara deskriptif. Data diklasifikasikan menjadi data kuantitatif yang berbentuk angka-angka dan data kualitatif yang diyatakan dalam kata-kata. Selanjutnya, hasil analisis data akan digunakan untuk menilai kualitas mobile learning terhadap materi organisasi arsitektur komputer yang ditinjau dari aspek kevalidan, keefektifan, dan kepraktisan. Validasi dilakukan dengan melakukan penskoran masing-masing item yang divalidasi dengan skala 1-5 dengan ketentuan:

Nilai $5=$ Sangat Setuju

Nilai $4=$ Setuju

Nilai 3 = Ragu-ragu

Nilai 2 = Setuju

Nilai 1 = Sangat Tidak Setuju 
Skor hasil analisis terhadap keprak-

Rumus yang digunakan dalam validasi produk pengembangan pada penelitian ini mengacu pada rumus statistik Aiken's V (Azwar, 2014, p. 112) yang dapat dilihat pada rumus 1

$$
\mathrm{V}=\sum \mathrm{s} /[\mathrm{n}(\mathrm{c}-1)]
$$

Keterangan :

$$
\begin{array}{ll}
\mathrm{S} & =\mathrm{r}-\mathrm{lo} \\
\mathrm{Lo} & =\text { Angka penilaian validitas yang } \\
& \text { terendah } \\
\mathrm{C} & =\text { Angka penilaian validitas yang } \\
& \text { tertinggi } \\
\mathrm{R} \quad & =\text { Angka yang diberikan oleh } \\
& \text { seorang penilaian }
\end{array}
$$

Untuk menentukan kevalidan dari mobile learning yang dikembangkan, kriteria yang digunakan yang disajikan dapat dilihat pada pada Tabel 1 .

Tabel 1. Kategori Kevalidan Mobile Learning

\begin{tabular}{ccc}
\hline No & Tingkat Pencapaian & Kategori \\
\hline 1 & $0-1,00$ & Valid \\
2 & $<0$ & Tidak valid \\
\hline
\end{tabular}

Tahap Evaluasi

Pada tahap evaluasi difokuskan untuk melakukan evaluasi rancangan mobile learning agar digunakan sesuai dengan harapan yaitu sebagai media pendukung pembelajaran mahasiswa pada materi organisasi arsitektur computer. Tahap evaluasi meliputi uji coba produk, tahap praktikalitas, dan tahap efektifitas. Untuk menguji kemudahan penggunaan media pembelajaran organisasi arsitektur dan komputer berbasis Android digunakan rumus uji praktikalitas. Data diperoleh dari angket yang diisi oleh dosen dan mahasiswa. Dari seluruh skor item yang diperoleh, kemudian ditabulasi dan dicari persentasenya dengan rumus.

Nilai Praktikalitas tisan oleh mahasiswa dan dosen dikelompokkan dalam kategori (Riduwan, 2015, p. 89) yang dapat dilihat pada Tabel 2.

Tabel 2. Kategori Kepraktisan

\begin{tabular}{ccc}
\hline No & $\begin{array}{c}\text { Tingkat } \\
\text { Pencapaian }(\%)\end{array}$ & Kategori \\
\hline 1 & $81-100$ & Sangat praktis \\
2 & $61-80$ & Praktis \\
3 & $41-60$ & Cukup Praktis \\
4 & $21-40$ & Kurang Praktis \\
5 & $0-20$ & Tidak Praktis \\
\hline
\end{tabular}

Sumber: Riduwan (2015, p. 89)

Efektif mobile learning ditentukan dengan cara mengetahui perbedaan hasil belajar mahasiswa kelas kontrol dan kelas ekperimen. Perbedaan yang dimaksud adalah selisih antara hasil belajar kelas kontrol dan kelas eksperimen, apabila peningkatan hasil belajar mahasiswa kelas ekperimen lebih tinggi daripada kelas kontrol, maka mobile learning dapat dikatakan efektif. Untuk pengujian signifikan dapat dilakukan dengan melakukan uji-t (Sugiyono, 2015 b, p. 78). Sebelum melakukan uji-t terlebih dahulu dilakukan uji normalitas dan uji homogenitas.

\section{Uji Normalitas}

Uji normalitas bertujuan untuk menentukan data yang telah dikumpulkan apakah telah berdistribusi normal atau tidak. Uji normalitas menggunakan software SPSS melihat nilai dari signifikan Kolmogorov Smirnov, pengambilan keputusan dalam uji normalitas adalah sebagai berikut:

Jika nilai Sig $\geq 0,05$, maka data berdistribusi normal

Jika nilai Sig $<0,05$, maka data tidak berdistribusi normal

Uji homogenitas

Uji Homogenitas bertujuan untuk mencari tahu apakah dari beberapa kelompok data penelitian memiliki varians yang sama atau tidak, untuk uji homogenitas menggunakan software SPSS (Priyatno, 
2010) melihat nilai dari signifikan homogenitas, pengambilan keputusan dalam uji homogenitas adalah sebagai berikut:

Jika nilai Sig $\geq 0,05$, maka data homogen Jika nilai Sig $<0,05$, maka data tidak homogen

\section{Uji-t}

Uji-t berfungsi untuk melihat perbedaan signifikan antara hasil tes kelas kontrol dan hasil tes kelas ekperimen. Pada uji-t ini digunakan software SPSS, untuk melihat perbedaan yang signifikan pada hasil belajar kelas kontrol dan kelas eksprimen dengan melihat signifikan pada hasil uji-t. Apabila hasil uji-t signifikan < 0,05 maka dapat diartikan terdapat perbedaan yang signifikan antara hasil belajar kelas kontrol dan hasil belajar kelas ekperimen.

\section{Hasil dan Pembahasan}

Hasil

Produk dari penelitian ini adalah media pembelajaran mobile learning berbasis Android untuk materi organisasi arsitektur komputer. Hasil rancangan tampilan halaman awal dapat dilihat pada Gambar 3.

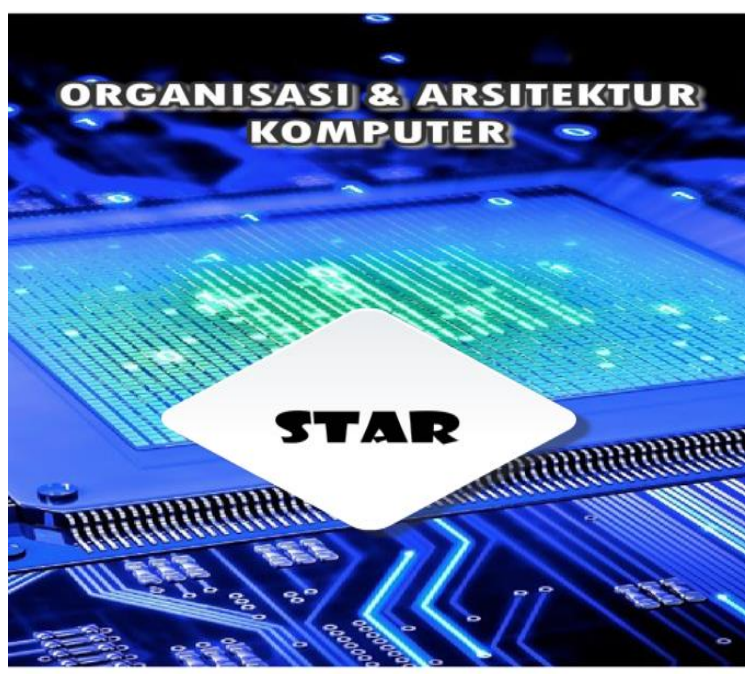

Gambar 3. Tampilan Halaman Home

Home merupakan halaman depan atau halaman utama yang akan tampil pada saat aplikasi pertama kali diakses atau dibuka oleh user atau pengguna. Halaman ini mengandung informasi mobile learning berbasis Android, yaitu berupa pengantar ucapan selamat datang pada aplikasi mobile learning organisasi arsitektur komputer, profil singkat pengembang, dan sponsor atau afiliasi dari peneliti.

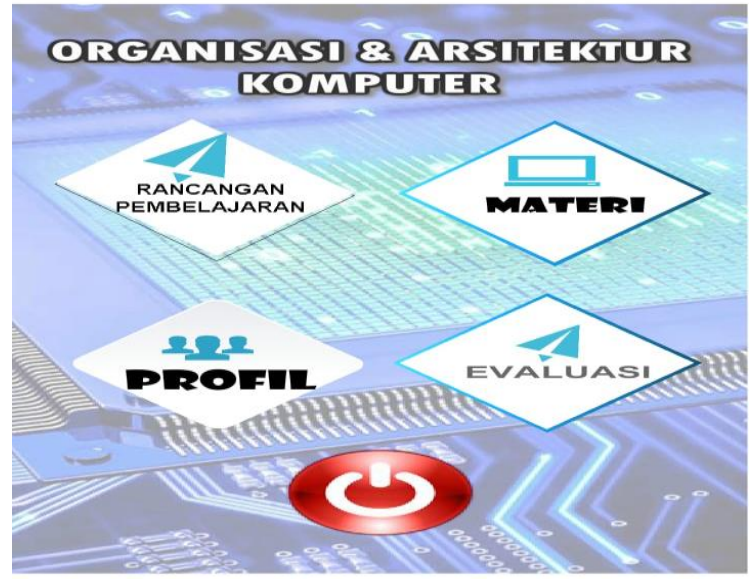

Gambar 4. Tampilan Halaman Menu

Selanjutnya, setelah usert telah melalui halaman home, maka aplikasi akan mengarahkan kepada halaman menu. Halaman menu adalah halaman yang ditujukkan atau difungsikan sebagai halaman kontrol dalam pengaksesan mobile learning yang dikembangkan. Pada halaman menu terdapat tombol untuk mengakses halaman rancangan pembelajaran, materi organisasi arsitektur komputer, profil, halaman evaluasi, dan tombol keluar. Tampilan halaman akses menu dapat dilihat pada Gambar 4.

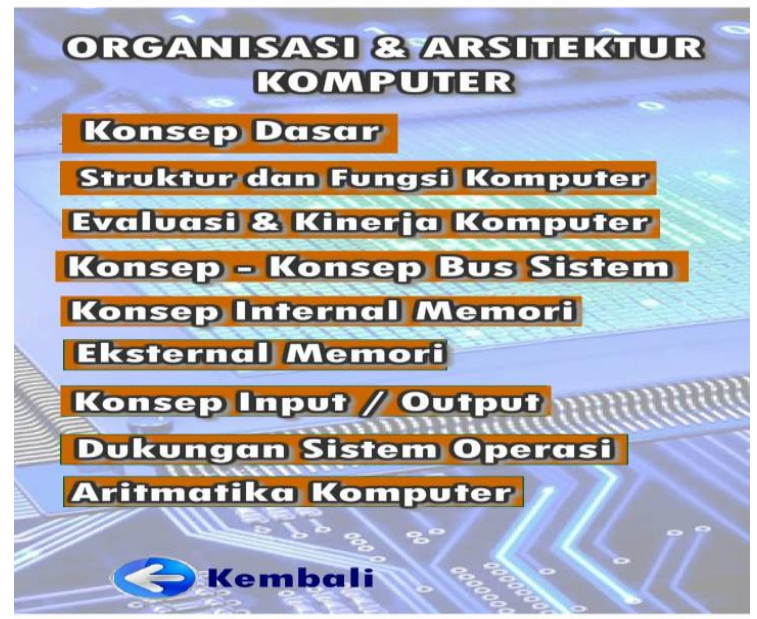

Gambar 5. Tampilan Halaman Materi 
Informasi materi yang disajikan pada halaman materi diambil dari mata kuliah organisasi arsitektur komputer yang disesuaikan dengan rancangan pembelajaran semester di program studi Pendidikan Teknik Informatika Universitas Putera Indonesia YPTK. Sub-sub materi pembahasan tentang organisasi arsitektur komputer dalam media pembelajaran mobile learning ini antara lain yaitu: 1.) Konsep dasar organisasi arsitektur komputer, 2.) Struktur dan fungsi komputer, 3.) Evaluasi dan kinerja komputer, 4.) Konsep-konsep bus sistem, 5.) Konsep internal memori, 6.) Eksternal memori, 7.) Konsep input atau output, 8.) Dukungan sistem operasi, dan 9.) Aritmatika komputer. Halaman materi dapat dilihat pada Gambar 5.

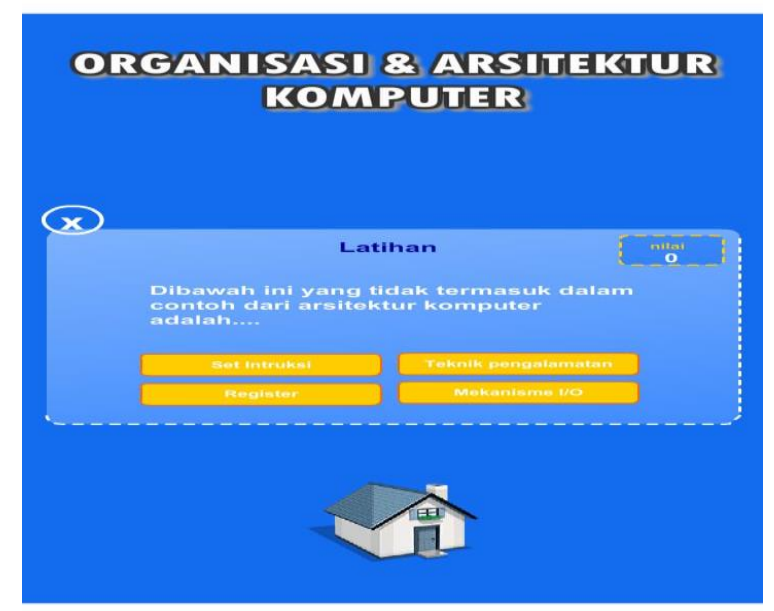

Gambar 6. Tampilan Halaman Evaluasi

Halaman evaluasi berisikan evaluasi pembelajaran yang dapat dilakukan atau dikerjakan oleh mahasiswa untuk mengukur seberapa besar pemahaman dan ketercapaian materi yang telah dipelajarinya dalam menggunakan atau mempelajari materi organisasi arsitektur komputer dengan menggunakan mobile learning yang telah dikembangkan. Halaman evaluasi menyajikan soal-soal yang berhubungan dengan mata kuliah organisasi arsitektur komputer dan aplikasi akan memberikan feedback terhadap hasil pengerjaan yang telah mahasiswa kerjakan pada saat mahasiswa telah selesai mengisi keseluruhan soal-soal evaluasi. Halaman evaluasi dapat dilihat pada Gambar 6.

\section{Pembahasan dan Hasil Uji Validitas}

Uji validitas adalah pengujian yang dilakukan untuk mengukur sah, atau valid tidaknya sebuah instrumen yang dalam hal ini ada produk media pembelajaran mobile learning berbasis Android. Uji validitas dilakukan oleh para ahli pakar untuk penilaian uji validitas desain dan materi masing-masing sebanyak 2 orang pakar atau ahli. Hasil uji validitas yang dilakukan dengan pakar materi mendapatkan hasil sebagai berikut: validator 1 dengan nilai rata-rata sejumlah 0,91 dan validator 2 dengan nilai rata-rata sejumlah 0,95 . Berdasarkan penliaian dari pakar materi tersebut, maka validitas dari segi materi masuk dalam kategori valid. Penilaian pada hasil uji validitas materi berdasarkan pada kriteria: aspek pembelajaran dan aspek materi dengan total jumlah butir pertanyaan sebanyak 20 buah. Hasil uji validitas materi tersebut dapat dilihat pada hasil pengolahan data yang berbentuk diagram distribusi frekuensi disajikan pada Gambar 7.

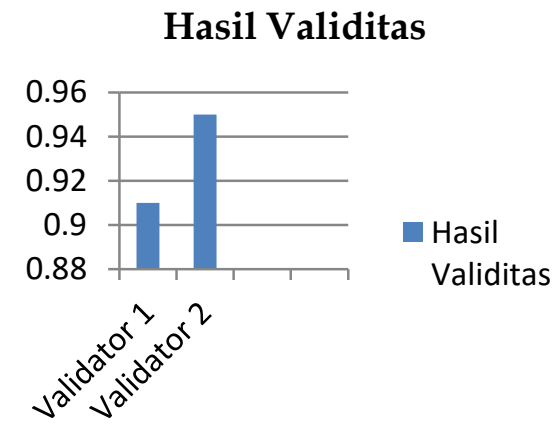

\section{Gambar 7. Diagram Hasil Uji Validitas Materi}

Hasil uji validitas yang dilakukan dengan pakar desain mendapatkan hasil sebagai berikut: validator 1 dengan rata-rata nilai sejumlah 0,9 dan validator 2 dengan rata-rata nilai sejumlah 0,89 . Berdasarkan penliaian dari pakar desain tersebut, maka validitas dari segi desain masuk dalam kategori valid. Penilaian pada hasil uji validitas desain berdasarkan pada kriteria: 
aspek navigasi, kemudahan, tulisan dan tampilan dengan total jumlah butir pertanyaan sebanyak 20 buah. Hasil uji validitas desain tersebut dapat dilihat pada hasil pengolahan data yang berbentuk diagram distribusi frekuensi yang dapat dilihat pada Gambar 8.

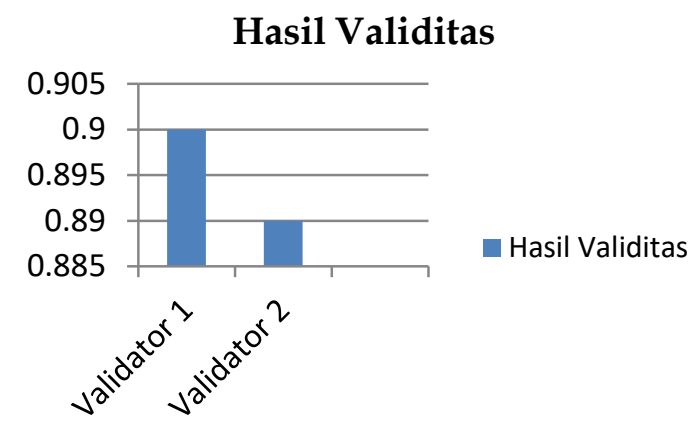

Gambar 8. Diagram Hasil Uji Validitas Desain

Uji Praktikalitas

Praktikalitas berkaitan dengan kemudahan dalam penggunaaan mobile learning yang dikembangkan. Data praktikalitas diperoleh melalui angket yang diisi oleh dua orang praktisi. Hasil uji praktikalitas berdasar respon dosen dapat divisualisasikan pada Tabel 3.

Tabel 3. Data Hasil Praktikalitas Berdasarkan Respon Dosen

\begin{tabular}{llllll}
\hline No & $\begin{array}{l}\text { Aspek } \\
\text { Penilaian }\end{array}$ & P1 & P2 & $\begin{array}{l}\text { Rata- } \\
\text { rata }\end{array}$ & Kategori \\
\hline 1 & Tekni & 88 & 88 & 88 & $\begin{array}{l}\text { Sangat } \\
\text { Praktis }\end{array}$ \\
2 & Isi & 96 & 96 & 96 & $\begin{array}{l}\text { Sangat } \\
\text { Praktis }\end{array}$ \\
3 & Disain & 94 & 90 & 92 & $\begin{array}{l}\text { Sangat } \\
\text { Praktis } \\
\text { Sangat } \\
\text { Praktis }\end{array}$ \\
\hline
\end{tabular}

Dimana: P1 = Praktisi 1 P2 = Praktisi 2

Hasil uji praktikalitas tersebut dapat dilihat pada hasil pengolahan data yang berbentuk diagram distribusi frekuensi yang dapat dilihat pada Gambar 9.

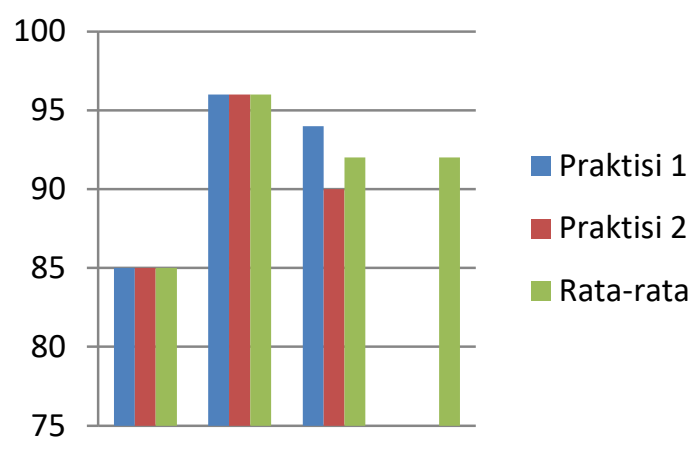

Gambar 9. Diagram Hasil Uji Praktikalitas Dosen

Praktikalitas mobile learning juga memerlukan masukan berupa respon dari peserta didik yang pada penelitian ini adalah mahasiswa program studi Pendidikan Teknik Informatika Universitas Putera Indonesia YPTK Padang. Data ini didapatkan setelah dilakukan pembelajaran, melalui angket yang diberikan kepada peserta didik. Mahasiswa merespon praktikalitas mobile learning melalui angket yang meliputi aspek kemudahan, motivasi, kebermanfaatan dan daya tarik mobile learning yang dikembangkan. Rata-rata persentase hasil respon mahasiswa merupakan acuan dalam penentuan kategori kepraktisan mobile learning yang dikembangkan. Hasil uji praktikalitas berdasar respon mahasiswa dapat dilihat pada Tabel 4.

Tabel 4. Data Hasil Praktikalitas Berdasarkan Respon Mahasiswa

\begin{tabular}{|c|c|c|c|}
\hline No & $\begin{array}{l}\text { Aspek } \\
\text { Penilaian }\end{array}$ & $\begin{array}{l}\text { Persentasi } \\
\text { Penilaian }\end{array}$ & Kategori \\
\hline 1 & Kemudahan & 87,5 & $\begin{array}{l}\text { Sangat } \\
\text { Praktis }\end{array}$ \\
\hline 2 & Motivasi & 87,1 & $\begin{array}{l}\text { Sangat } \\
\text { Praktis }\end{array}$ \\
\hline 3 & Kemenarikan & 85,0 & $\begin{array}{l}\text { Sangat } \\
\text { Praktis }\end{array}$ \\
\hline 4 & $\begin{array}{l}\text { Keberman- } \\
\text { faatan }\end{array}$ & 90,8 & $\begin{array}{l}\text { Sangat } \\
\text { Praktis }\end{array}$ \\
\hline \multicolumn{2}{|c|}{ Rata-rata } & 87,61 & $\begin{array}{l}\text { Sangat } \\
\text { Praktis }\end{array}$ \\
\hline
\end{tabular}

Hasil uji praktikalitas tersebut dapat dilihat pada hasil pengolahan data yang 
berbentuk diagram distribusi frekuensi yang dapat dilihat pada Gambar 10.

\section{Persentase Penilaian}

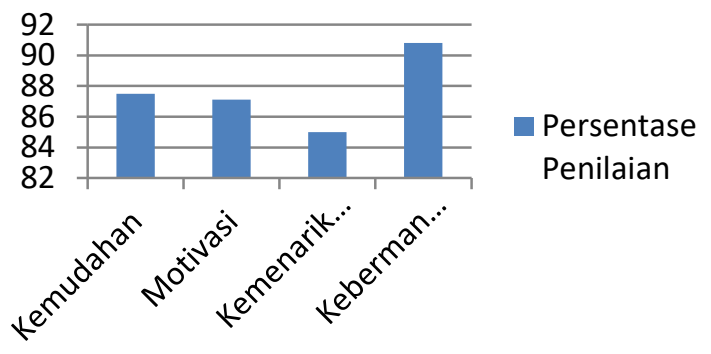

Gambar 10. Diagram Hasil Uji Praktikalitas Dosen

Berdasarkan hasil analisis praktikalitas respon dosen dan mahasiswa terhadap praktikalitas mobile learning, dapat disimpulkan bahwa mobile learning yang dikembangkan berada pada kategori sangat praktis. Hal ini menandakan bahwa mobile learning yang dikembangkan dapat memudahkan siswa dalam memahami pembelajaran organisasi arsitektur komputer.

\section{Uji Efektifitas}

Hasil uji efektifitas didapatkan melalui pengujian terhadap kelas kontrol atau kelas yang tidak menggunakan media pembelajaran mobile learning dengan kelas eksperimen atau kelas yang mendapatkan perlakuan/menggunakan media pembelajaran mobile learning. Hasil belajar kelas kontrol dari 16 orang mahasiswa didapat hasil untuk postest dengan rata-rata nilai sebesar 74,56, sedangkan hasil belajar kelas eksperimen dari 16 orang mahasiswa didapat hasil untuk postest dengan nilai rata-rata sebesar 82,25 . Selanjutnya untuk mengetahui signifikansi perbedaan hasil belajar kedua kelas maka dilakukan uji-t dengan mela-kukan uji normalitas dan uji homogenitas.

\section{Uji Normalitas}

Dari hasil uji normalitas yang dilakukan dengan software SPSS, didapati nilai yang dapat dilihat pada Tabel 5 .
Tabel 5. Normalitas Kelas Kontrol dan Eksperimen

\begin{tabular}{lccc}
\hline & & Kontrol & Eksperimen \\
\hline \multicolumn{1}{c}{$\mathrm{N}$} & 16 & 16 \\
Normal & Mean & 74,560 & 82,250 \\
Parameters & $\begin{array}{c}\text { Std Devi- } \\
\text { ation }\end{array}$ & 4,147 & 82,25 \\
Most & Absolute & 0,230 & 0,204 \\
Extreme & Positive & 0,114 & 0,204 \\
Differences & Negative & $-0,230$ & $-0,119$ \\
Kolmogoro & & & \\
v-Sminorv & & 0,918 & 0,818 \\
Z & & & \\
Asymp. & & 0,368 & 0,515 \\
Sig. & & & \\
(2-tailed) & & & \\
\hline
\end{tabular}

Berdasarkan Tabel 5, didapat nilai signifikan untuk kelas kontrol sebesar 0,368 dan untuk kelas eksperimen sebesar 0,515, jadi dapat disimpulkan bahwa data berdistribusi normal karena $>0,05$.

\section{Uji Homogenitas}

Hasil uji homogenitas hasil belajar kelas kontrol dan eksperimen adalah sebagai berikut:

$\begin{array}{ll}\text { levene statistic } & =1,110 \\ \text { df1 } & =5 \\ \text { df2 } & =9 \\ \text { sig } & =0,419\end{array}$

Dari hasil signifikan sebesar 0.419 yang lebih besar dari 0,05, maka antara kelas kontrol dan eksperimen mempunyai varians yang homogen.

Uji-t

Berdasarkan uji normalitas dan homogenitas varian posttest didapatkan hasil bahwa kedua kelas tersebut terdistribusi secara normal dan mempunyai varian yang homogen, sehingga uji perbedaan kedua rata-rata kelas dapat dilihat sebagai berikut:

$\begin{array}{ll}\text { Mean } & =-7,688 \\ \text { Std. Deviation } & =4.316 \\ \text { Std. Eror Mean } & =1,079 \\ \mathrm{t} & =-7,124 \\ \mathrm{df} & =15 \\ \operatorname{sig}(2 \text {-tailed) } & =0,000\end{array}$


Berdasarkan data yang diperoleh dari hasil uji efektifitas mobile learning, maka peneliti dapat menjelaskan bahwa terdapat perbedaan yang signifikan pada hasil kelas kontrol dan kelas eksperimen. Mekanisme pengembangan mobile learning pada materi organisasi arsitektur komputer berbasis Android sebagai media pendukung kebutuhan yang dibutuhkan oleh mahasiswa dan dosen dapat mempermudah pekerjaan dosen dalam proses evaluasi belajar mahasiswa dengan adanya fitur latihan dan pemberian nilai secara otomatis. Sistem ini melakukan penyampaian data materi perkuliahan serta pemberian tugas dari dosen dapat diberikan secara cepat dan langsung bisa diterima oleh mahasiswa.

Pengujian validitas pada penelitian ini diisi oleh 4 orang dosen dengan hasil uji validitas yang dilakukan dengan pakar media serta pakar materi didapatkan hasil dari perhitungan validasi materi yaitu validator 1 dengan rata-rata sebesar 0,91, validator 2 dengan penilaian rata-rata 0,95 dan validasi desain yaitu validator 1 dengan penilaian rata-rata 0,9 , validator 2 dengan penilaian rata-rata 0,89 . Dari hasil perhitungan validasi materi dan desain secara keseluruhan berada pada kategori valid. Secara keseluruhan penilaian kepraktisan terhadap media pembelajaran mobile learning berbasis Android berdasarkan respon praktisi atau dosen adalah pada nilai ratarata sebesar $92 \%$, dan penilaian kepraktisan berdasarkan respon mahasiswa adalah pada nilai rata-rata sebesar $87,61 \%$, sehingga tingkat praktikalitasnya dapat diinterprestasikan praktis digunakan sebagai media pembelajaran. Hasil belajar kelas kontrol (tidak menggunakan mobile learning) dari 16 orang mahasiswa didapat hasil untuk postest $(74,56)$, namun hasil belajar kelas eksperimen (menggunakan mobile learning) dari 16 orang mahasiswa didapat hasil untuk postest $(82,25)$. Dengan aplikasi mobile learning ini dapat melengkapi sistem belajar mengajar antara dosen dan mahasiswa pada mata pelajaran organisasi arsitektur komputer yang saat ini dilakukan secara konvensional menjadi lebih cepat dan mudah.

\section{Simpulan}

Berdasarkan hasil pengujian yang telah dilakukan, maka uji validitas mobile learning berbasis Android sebagai media pembelajaran mandiri untuk materi organisasi arsitektur komputer masuk dalam kategori valid. Pada uji praktikalitas mobile learning berbasis Android sebagai media pembelajaran mandiri praktis digunakan pada mata kuliah organisasi arsitektur komputer. Berdasarkan hasil uji efektifitas, maka aplikasi ini layak untuk diterapkan dan dikembangan lebih lanjut, sehingga dapat meningkatkan hasil pemahaman terhadap materi dapat ditingkatkan lebih baik lagi. Secara keseluruhan pembelajaran dengan menggunakan media mobile learning membangun pembelajaran yang lebih menarik dan memberikan pengalaman yang baru untuk mahasiswa. Karakteristik mobile learning yang dapat digunakan dimana saja dan kapan saja membuat mahasiswa lebih mudah dalam melakukan pengulangan pembelajaran di rumah atau belajar mandiri. Fitur kuis atau evaluasi yang terdapat dalam media mobile learning digunakan mahasiswa untuk mengukur kemampuannya dan pemahamannya terhadap konsep organisasi arsitektur dan komputer yang dapat dilakukan tanpa dibatasi waktu dan tempat.

\section{Daftar Pustaka}

Aditya, B. R., Nurhas, I., \& Pawlowski, J. (2019). Towards successful implementation of a virtual classroom for vocational higher education in Indonesia. $8^{\text {th }}$ International Workshop, LTEC 2019, Spain. https:/ / doi.org/10.1007/978-3-03020798-4_14

Arsyad, A. (2016). Media Pembelajaran. Jakarta: Raja Grafindo Persada.

Azwar, S. (2014). Validitas dan reabilitas. 
Yogyakarta: pustaka Pelajar.

Bhati, A., \& Song, I. (2019). New methods for collaborative experiential learning to provide personalised formative assessment. International Journal of Emerging Technologies in Learning, 14(7), 179-195.

doi:https:// doi.org/10.3991/ijet.v14i0 7.9173

Cahyana, U., Paristiowati, M., Nurhayadi, M. F., \& Hasyirin, S. N. (2017). Studi tentang motivasi belajar siswa pada penggunaan media mobile game base learning dalam pembelajaran laju reaksi kimia. Jurnal Teknologi Pendidikan, 19(2), 143-155. doi:https:// doi.org/10.21009/JTP1902 .6

Chatwattana, P., \& Nilsook, P. (2017) A Web-based learning system using project-based learning and imagineering. International Journal of Emerging Technologies in Learning, 12(5), 4-22. doi:https:/ / doi.org/10.3991/ijet.v12i0 5.6344

Darmawan, D. (2016). Mobile learning. Bandung: PT Remaja Rosda karya Offset.

Faisal, F., \& Martin, S. N. (2019). Science education in Indonesia: past, present, and future. Asia-Pacific Science Education, 5(4), 1-29. doi:https:// doi.org/10.1186/s41029019-0032-0

Gregory, S., \& Tyrrel, M. B., (2017). Digital learner presence and online teaching tools: higher cognitive requirements of online learners for effective learning. Research and Practice in Technology Enhanced Learning, 12(18), 1-17.

doi:https:/ / doi.org/10.1186/s41039017-0059-3

Kasatria, R. J., (2014). Pengembangan teknologi informasi mobile learning Fakultas Teknik Universitas Diponegoro berbasis android. Jurnal Teknologi dan Sistem Komputer, 2(4), 241-248. doi:https:// doi.org/10.14710/jtsisko m.2.4.2014.241-248

Mogase, R. C., \& Alexander, P. M, (2018, November). An interactive mobile computing model to enhance personalized learning for at-risk students in South African higher learning. IEEE 9 ${ }^{\text {th }}$ Annual Information Technology, Electronics and Mobile Communication Conference (IEMCON), Vancouver, Canada. doi:10.1109/IEMCON.2018.8614838

Priyatno, D. (2010). Paham analisa statistik data dengan SPSS. Jakarta: Media kom.

Riduwan, R. (2015). Belajar mudah penulisan untuk guru-karyawan dan peneliti pemula. Bandung: Alfabeta.

Sugiyono, S. (2015a). Metode penenlitian kuantitatif, kualitatif, dan RED. Bandung: Alfabeta.

Sugiyono, S. (2015b). Statistika untuk penelitian. Bandung: Alfabeta. 